\title{
Localized Gastric Amyloidosis with Kappa and Lambda Light Chain Co-Expression
}

\author{
Yong Hwan Ahn', Ye Young Rhee ${ }^{2}$, Suck Chei Choi ${ }^{3}$ and Geom Seog $\mathrm{Seo}^{3}$ \\ ${ }^{1}$ Department of Internal Medicine, Plus Internal Medicine Clinic, Suncheon, ${ }^{2}$ Anatomic Pathology Reference Lab, Seegene Medical \\ Foundation, Seoul, ${ }^{3}$ Department of Internal medicine, Digestive Disease Research Institute, Wonkwang University College of Medicine, \\ Iksan, Korea
}

Esophagogastroduodenoscopy for cancer screening was performed in a 55-year-old woman as part of a health screening program, and revealed a depressed lesion approximately $20 \mathrm{~mm}$ in diameter in the lesser curvature of the mid-gastric body. Several biopsy specimens were collected as the lesion resembled early gastric cancer; however, histopathologic evaluation revealed chronic active gastritis with an ulcer and amorphous eosinophilic material deposition. Congo red staining identified amyloid proteins, and applegreen birefringence was shown using polarized light microscopy. Immunohistochemical staining revealed the presence of kappa and lambda chain-positive plasma cells. There was no evidence of underlying plasma cell dyscrasia or amyloid deposition in other segments of the gastrointestinal tract. Echocardiography and computed tomography of the chest, abdomen, and pelvis did not show any significant findings. Thus, the patient was diagnosed with localized gastric amyloidosis with kappa and lambda light chain coexpression. Clin Endosc 2018;51:285-288

Key Words: Localized gastric amyloidosis; Light chain amyloidosis; Co-expression

\section{INTRODUCTION}

Amyloidosis, which results from the accumulation of a large amount of fibrillar proteins, is classified based on the identity of the corresponding precursor proteins, and can subvert tissue architecture, causing organ dysfunction. ${ }^{1}$ The gastrointestinal (GI) tract is often involved in patients with systemic amyloidosis. ${ }^{2}$ Conversely, localized amyloidosis, which can occur in various organs, rarely involves the GI tract, particularly the stomach. ${ }^{3}$ Esophagogastroduodenoscopy (EGD) with tissue biopsy stained with Congo red to identify amyloid proteins is indispensable for the diagnosis of localized gastric amyloido-

Received: July 19, 2017 Revised: August 24, 2017

Accepted: August 30, 2017

Correspondence: Geom Seog Seo

Department of Internal Medicine, Digestive Disease Research Institute, Wonkwang University College of Medicine, 895 Muwang-ro, Iksan 54538, Korea Tel: +82-63-859-2565, Fax: +82-63-855-2025, E-mail: medsgs@wku.ac.kr ORCID: https://orcid.org/0000-0001-8789-7989

(c) This is an Open Access article distributed under the terms of the Creative Commons Attribution Non-Commercial License (http://creativecommons.org/ licenses/by-nc/3.0) which permits unrestricted non-commercial use, distribution, and reproduction in any medium, provided the original work is properly cited. sis, given that more than half the patients are asymptomatic and present variable endoscopic features. ${ }^{4}$ Localized gastric amyloidosis with the generalized deposition of excessive kap$\mathrm{pa}(\kappa)$ or lambda $(\lambda)$ light chains is the most common type of immunoglobulin light-chain (AL) amyloidosis. However, few studies have reported localized gastric amyloidosis with co-expression of $\kappa$ and $\lambda$ light chains. ${ }^{3,4}$ We report a case of localized gastric amyloidosis with $\kappa$ and $\lambda$ light chain co-expression diagnosed by EGD for cancer screening in an asymptomatic patient.

\section{CASE REPORT}

A 55-year-old woman visited our clinic as part of the national health screening program, which included EGD for cancer screening. She had been diagnosed with breast cancer 2 years prior at our clinic, had undergone a simple excision of the left breast mass, and had been taking an oral nonsteroidal aromatase inhibitor (letrozole). She had no clinical complaints, and general physical findings were unremarkable. 
Laboratory tests in the national health screening program, which include measurements of hemoglobin, aminotransferase, fasting glucose, and creatinine and determination of the cholesterol profile, revealed no abnormal findings. EGD revealed the presence of a round lesion measuring approximately $20 \mathrm{~mm}$ in diameter with a central depression in the lesser curvature of the mid-gastric body. The lesion had irregular edges and slightly heaped-up margins, with focal distorted vessels and an uneven pale-colored base (Fig. 1). On EGD, the lesion resembled early gastric cancer; therefore, several biopsy specimens were collected. However, histopathologic examination revealed dense lymphoplasmacytic infiltration and amorphous eosinophilic material deposition in the lamina propria, without malignant findings or lymphoepithelial lesions. Congo red staining identified amy-

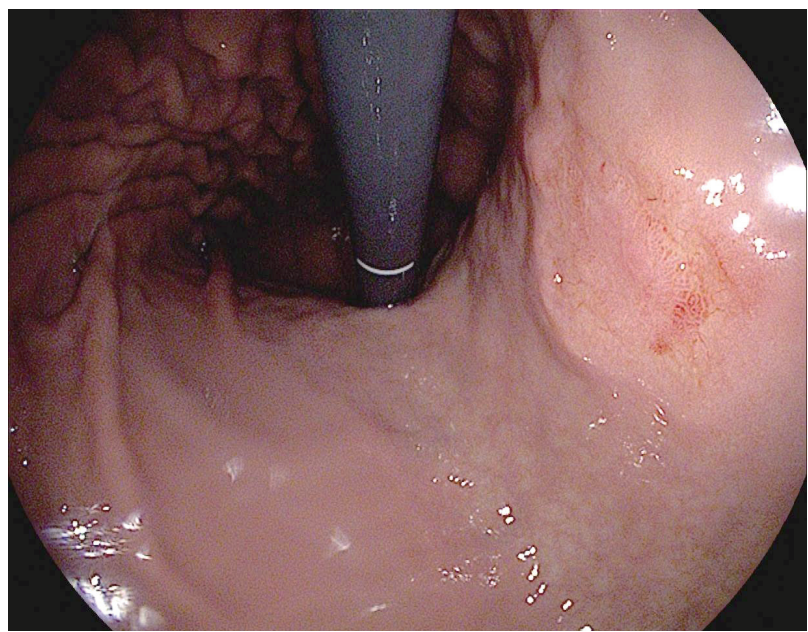

Fig. 1. Endoscopic findings. A round lesion approximately $20 \mathrm{~mm}$ in diameter, with central depression and a pale-colored base on the lesser curvature of the mid-gastric body. loid proteins (Fig. 2A). Apple-green birefringence was shown using polarized light microscopy (Fig. 2B). Immunohistochemical staining to classify amyloid protein subtypes revealed that all plasma cells within the mucosal layer were $\kappa$ and $\lambda$ chain-positive (Fig. 3). Random tissue biopsies, which were performed in the duodenum and colon to evaluate the presence of amyloid proteins in other GI regions, were negative. Echocardiography did not show any abnormalities other than abnormal relaxation and diastolic dysfunction in the left ventricle. Computed tomography of the chest, abdomen, and pelvis did not show any significant findings. Additional laboratory findings for serum immunoglobulin (Ig) levels (IgG, $1,297 \mathrm{mg} / \mathrm{dL}$ [normal range, 700-1,600 mg/dL]; IgA, $182 \mathrm{mg} / \mathrm{dL}$ [normal range, $40-230 \mathrm{mg} / \mathrm{dL}$ ]; IgM, $147 \mathrm{mg} / \mathrm{dL}$ [normal range, $70-400 \mathrm{mg} / \mathrm{dL}$; $\beta_{2}$-microglobulin, $1.37 \mathrm{mg} / \mathrm{dL}$ [normal range, $0.76-2.13 \mathrm{mg} / \mathrm{dL}$ ]; free $\kappa$ chain, $12.31 \mathrm{mg} / \mathrm{dL}$ [normal range, $3.30-19.4 \mathrm{mg} / \mathrm{dL}$ ]; and free $\lambda$ chain, $13.79 \mathrm{mg} / \mathrm{dL}$ [normal range, $5.71-26.3 \mathrm{mg} / \mathrm{dL}]$ ) and serum complement levels $(\mathrm{C} 3,120 \mathrm{mg} / \mathrm{dL}$ [normal range, $90-180 \mathrm{mg} / \mathrm{dL}$ ] and C4, 38 $\mathrm{mg} / \mathrm{dL}$ [normal range, $10-40 \mathrm{mg} / \mathrm{dL}$ ]) were normal, whereas those for serum antinuclear, rheumatoid factor, and antineutrophilic cytoplasmic antibodies as well as urinary Bence Jones protein were negative. Immunoelectrophoresis results of serum and urine were nonspecific. A bone marrow biopsy was not performed due to normal serum and urine Ig levels and negative immunoelectrophoresis results. Based on these data, the patient was diagnosed with localized gastric amyloidosis with co-expression of Ig $\kappa$ and $\lambda$ light chains. Because she had no symptoms, the patient did not receive any further treatment. In the first year since the initial diagnosis, the patient remained in good condition, no significant changes in the lesion were observed in the biannual endoscopy, and there were no abnormal laboratory findings.
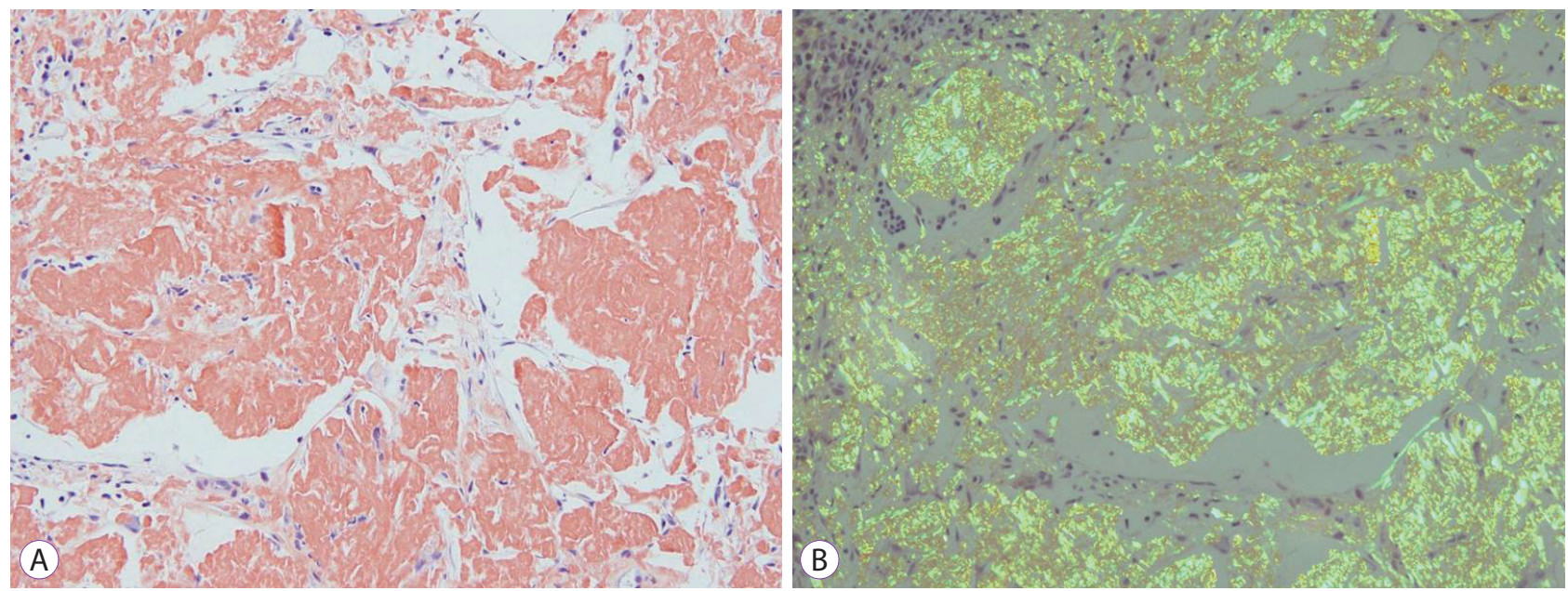

Fig. 2. Histopathologic findings. (A) Congo red staining shows amorphous amyloid proteins (Congo red, $\times 200)$. (B) Apple-green birefringence is shown using polarized light microscopy after Congo red staining (Congo red, $\times 200$ ). 

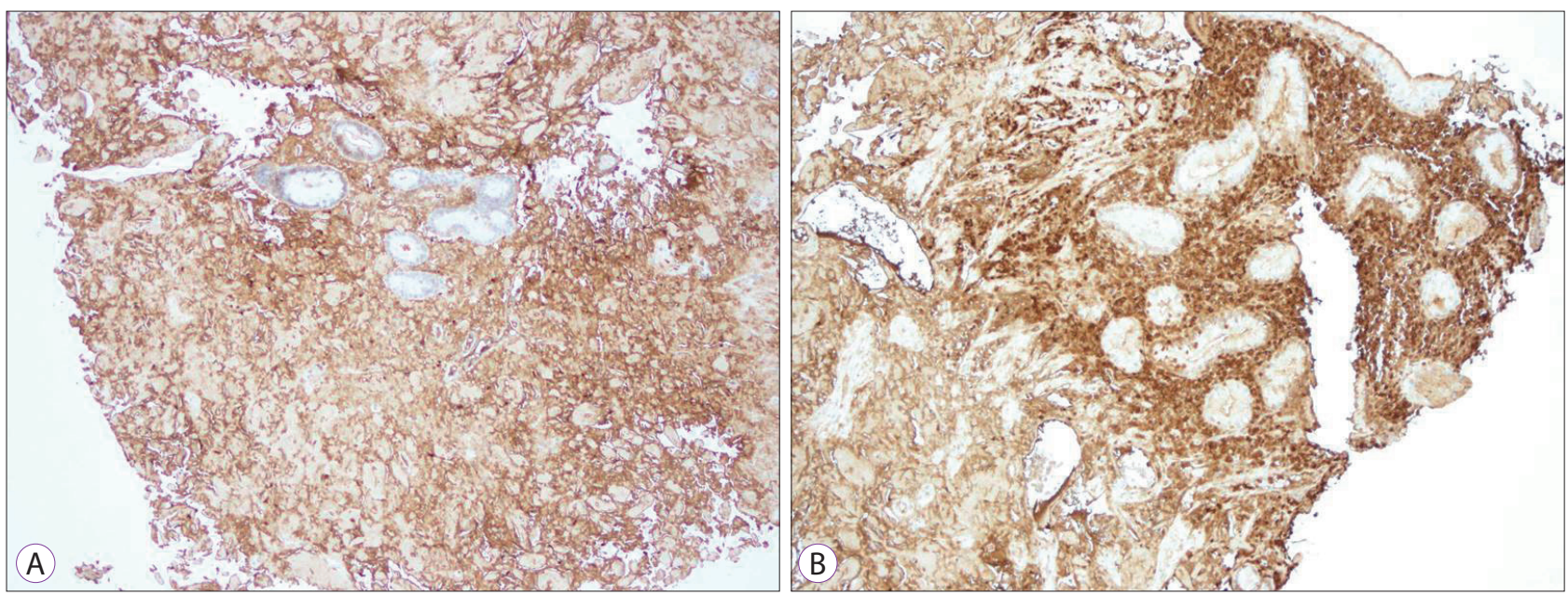

Fig. 3. Immunohistochemical staining shows the presence of plasma cells with co-expression of kappa (A) and lambda (B) light chains in the mucosal layer.

Table 1. Clinical, Endoscopic, and Histopathologic Findings of Cases with Localized Gastric Immunoglobulin Light-Chain Amyloidosis

\begin{tabular}{|c|c|c|c|c|c|c|c|}
\hline Study & Age/Sex & Symptom & Localization & EGD findings & Amyloid type & Treatment & Prognosis \\
\hline $\begin{array}{l}\text { Björnsson et } \\
\text { al. }^{8}(1987)\end{array}$ & $60 / \mathrm{F}$ & Hematemesis & Stomach (Body) & $\begin{array}{l}\text { Thickened \& } \\
\text { irregular folds }\end{array}$ & $\begin{array}{l}\mathrm{AL} \\
\text { (undetermined) }\end{array}$ & $\begin{array}{l}\text { Surgery (partial } \\
\text { gastric resection) }\end{array}$ & Survival \\
\hline $\begin{array}{l}\text { Yanai et al. }{ }^{9} \\
(1991)\end{array}$ & $52 / \mathrm{F}$ & None & $\begin{array}{l}\text { Stomach (Lower } \\
\text { body) }\end{array}$ & Erosion & $\mathrm{AL}(\lambda$ chain $)$ & EMR (strip biopsy) & Survival \\
\hline $\begin{array}{l}\text { Lee et al. }^{10} \\
(1998)\end{array}$ & $53 / \mathrm{F}$ & Dyspepsia & $\begin{array}{l}\text { Stomach (Antrum, } \\
\text { mid and lower body) }\end{array}$ & $\begin{array}{l}\text { Thickened \& } \\
\text { protruding folds }\end{array}$ & $\begin{array}{l}\mathrm{AL} \\
\text { (undetermined) }\end{array}$ & $\begin{array}{l}\text { Cisapride, } \mathrm{H}_{2} \\
\text { blocker }\end{array}$ & Survival \\
\hline $\begin{array}{l}\text { Lee et al. }{ }^{11} \\
(2011)\end{array}$ & $60 / \mathrm{F}$ & $\begin{array}{l}\text { Postprandial } \\
\text { pain }\end{array}$ & Stomach (Mid body) & Thickened folds & $\begin{array}{l}\text { AL } \\
\text { (undetermined) }\end{array}$ & - & - \\
\hline $\begin{array}{l}\text { Kamata et al. } \\
(2012)\end{array}$ & $76 / \mathrm{F}$ & $\begin{array}{l}\text { Epigastric } \\
\text { discomfort }\end{array}$ & $\begin{array}{l}\text { Stomach (Upper to } \\
\text { lower body) }\end{array}$ & $\begin{array}{l}\text { Reddish \& swollen } \\
\text { folds }\end{array}$ & AL ( $\kappa \& \lambda$ chain $)$ & - & Survival \\
\hline $\begin{array}{l}\text { Ebato et al. } \\
\quad(2012)\end{array}$ & $77 / \mathrm{F}$ & None & $\begin{array}{l}\text { Stomach (Lower } \\
\text { body) }\end{array}$ & $\begin{array}{l}\text { Flat depressed (easy } \\
\text { bleeding) }\end{array}$ & $\begin{array}{l}\text { AL } \\
\text { (undetermined) }\end{array}$ & ESD & Survival \\
\hline \multirow{5}{*}{$\begin{array}{l}\text { Katoh et al. } \\
\quad(2015)\end{array}$} & $31 / \mathrm{F}$ & Gastralgia & Stomach & Nodular lesions & AL ( $\lambda$ chain $)$ & PPI & Survival \\
\hline & $44 / \mathrm{M}$ & None & Stomach & $\begin{array}{l}\text { Multiple nodular } \\
\text { lesions }\end{array}$ & AL ( $\lambda$ chain $)$ & - & Survival \\
\hline & $55 / \mathrm{F}$ & None & Stomach & Depressed lesion & AL ( $\kappa$ chain $)$ & - & Survival \\
\hline & $67 / \mathrm{F}$ & None & Stomach & Chronic gastritis & AL ( $\kappa$ chain) & - & Survival \\
\hline & $38 / \mathrm{F}$ & None & $\begin{array}{l}\text { Stomach \& } \\
\text { Duodenum }\end{array}$ & $\begin{array}{l}\text { Polypoid } \\
\text { protrusions }\end{array}$ & AL ( $\lambda$ chain $)$ & - & Survival \\
\hline $\begin{array}{l}\text { Yamaguchi et } \\
\text { al. }^{14}(2015)\end{array}$ & $49 / \mathrm{M}$ & Unknown & $\begin{array}{l}\text { Stomach (Lower } \\
\text { body) }\end{array}$ & SMT-like lesion & $\begin{array}{l}\text { AL } \\
\text { (undetermined) }\end{array}$ & - & Survival \\
\hline $\begin{array}{l}\text { Kagawa et al. } \\
(2016)\end{array}$ & $73 / \mathrm{M}$ & None & $\begin{array}{l}\text { Stomach (Lower } \\
\text { body) }\end{array}$ & Depressed lesion & $\begin{array}{l}\text { AL } \\
\text { (undetermined) }\end{array}$ & - & Survival \\
\hline $\begin{array}{l}\text { Present case } \\
\text { (2017) }\end{array}$ & $55 / \mathrm{F}$ & None & Stomach (Mid body) & Depressed lesion & $\mathrm{AL}(\kappa \& \lambda$ chain $)$ & - & Survival \\
\hline
\end{tabular}

EGD, esophagogastroduodenoscopy; AL, immunoglobulin light-chain; $\kappa$, kappa; $\lambda$, lambda; EMR, endoscopic mucosal resection; ESD, endoscopic submucosal dissection; PPI, proton pump inhibitor; SMT, submucosal tumor.

\section{DISCUSSION}

AL amyloidosis is characterized by the clonal expansion of plasma cells that produce monoclonal $\kappa$ or $\lambda$ light chains that are deposited as insoluble fibrillar proteins in tissues and disturb organ function. ${ }^{1,5} \mathrm{AL}$ amyloidosis occurs in up to $15 \%$ of patients with plasma cell neoplasms. ${ }^{1}$ Localized AL amyloidosis accounts for approximately $12 \%$ of all AL amyloidosis cases, and the GI tract is involved in $7.7 \%$ of these cases. ${ }^{6,7}$ Localized AL amyloidosis restricted to the stomach is 
extremely rare; clinical, endoscopic, and histopathologic findings from our review of cases in the literature are summarized in Table $1 .{ }^{4,8-15}$ Over $60 \%$ of patients had no symptoms and tended to remain asymptomatic throughout the observation period. Although the body of the stomach was involved in most cases, gross findings by EGD varied, including erosion, nodular appearance, thickened or swollen folds, submucosal localization, polypoid protrusion, and depressed lesions. Although endoscopic ultrasound (EUS), endoscopic mucosal resection (EMR), and endoscopic submucosal dissection (ESD) were not performed in the patient discussed here, they can be used for definitive diagnosis and to rule out malignancy. ${ }^{11-14}$ Because the gross appearance of this lesion usually resembles malignant lymphoma or gastric cancer, such as that observed in this case study, staining using Congo red should be performed to confirm the presence of amyloid proteins and ensure an accurate diagnosis. ${ }^{12,1415}$ If the lesion contains amyloid deposits, determining the extent of amyloidosis is critical. ${ }^{5-7}$ The prognosis of systemic AL amyloidosis is worse in cases involving the GI tract than in those not involving the tract, and the mortality rate is high. ${ }^{2,5}$ However, only $2 \%$ of patients with localized AL amyloidosis exhibited symptom progression, and overall survival was not different from that of the general population, except in cases involving the lungs. ${ }^{7}$ Localized $\mathrm{AL}$ amyloidosis involving the stomach was also associated with a good prognosis, and long-term outcomes were excellent. ${ }^{4,-15}$ Therefore, if localized gastric AL amyloidosis is confirmed by histopathology, it is likely that invasive inspections, such as EUS, EMR, or ESD, are not necessary.

Only $2 \%$ of plasma cell neoplasms show biclonal gammopathy on protein electrophoresis, and few cases of plasma cell neoplasms with co-expression of $\kappa$ and $\lambda$ light chains have been reported in the literature. ${ }^{16,17}$ In localized AL amyloidosis involving the GI tract, clonal plasma cells express the $\lambda$ light chain more frequently than the $\kappa$ light chain, with very few reports of AL amyloidosis showing co-expression of $\kappa$ and $\lambda$ light chains. ${ }^{3,7}$ There is only one reported case of localized gastric $\mathrm{AL}$ amyloidosis expressing both $\kappa$ and $\lambda$ light chains. ${ }^{12}$ In that case, plasma cells expressing the $\kappa$ light chain were distributed only in the superficial lamina propria, whereas those expressing the $\lambda$ isotype were spread throughout the mucosa. In contrast, plasma cells showing co-expression of $\kappa$ and $\lambda$ light chains were spread throughout the mucosal layer in the current case. It remains unclear whether the general distribution of plasma cells in localized AL amyloidosis showing co-expression of light chains affects disease prognosis. Based on the cases reported to date, the prognosis of patients with localized gastric amyloidosis showing co-expression of the abovementioned light chains is similar to that of patients expressing only one light-chain isotype. ${ }^{4,9,12}$

We report a very rare case of localized gastric AL amyloidosis with $\kappa$ and $\lambda$ light chain co-expression, confirmed by immunohistochemistry; to date, this condition has not been reported.

\section{Conflicts of Interest}

The authors have no financial conflicts of interest.

\section{REFERENCES}

1. Merlini G, Bellotti V. Molecular mechanisms of amyloidosis. N Engl J Med 2003;349:583-596.

2. Lim AY, Lee JH, Jung KS, et al. Clinical features and outcomes of systemic amyloidosis with gastrointestinal involvement: a single-center experience. Korean J Intern Med 2015;30:496-505.

3. Biewend ML, Menke DM, Calamia KT. The spectrum of localized amyloidosis: a case series of 20 patients and review of the literature. Amyloid 2006;13:135-142.

4. Katoh N, Matsuda M, Ikeda S. Clinical, endoscopic, and histopathological features of localized immunoglobulin light chain (AL) amyloidosis in the gastrointestinal tract. Amyloid 2015;22:254-256.

5. Gertz MA. Immunoglobulin light chain amyloidosis: 2016 update on diagnosis, prognosis, and treatment. Am J Hematol 2016;91:947-956.

6. Mahmood S, Bridoux F, Venner CP, et al. Natural history and outcomes in localised immunoglobulin light-chain amyloidosis: a long-term observational study. Lancet Haematol 2015;2:e241-e250.

7. Kourelis TV, Kyle RA, Dingli D, et al. Presentation and outcomes of localized immunoglobulin light chain amyloidosis: the Mayo Clinic experience. Mayo Clin Proc 2017;92:908-917.

8. Björnsson S, Jóhannsson JH, Sigurjónsson F. Localized primary amyloidosis of the stomach presenting with gastric hemorrhage. Acta Med Scand 1987;221:115-119.

9. Yanai H, Fuji T, Tada M, et al. Localized amyloidosis of the stomach. Gastrointest Endosc 1991;37:408-409.

10. Lee SH, Rhee PL, Kim JJ, et al. A case of primary gastric amyloidosis diagnosed by endoscopy. Korean J Gastrointest Endosc 1998;18:561-566.

11. Lee YN, Hong SJ, Kim HK. [Localized gastric amyloidosis]. Korean J Gastroenterol 2011;58:117-120.

12. Kamata T, Suzuki H, Yoshinaga S, et al. Localized gastric amyloidosis differentiated histologically from scirrhous gastric cancer using endoscopic mucosal resection: a case report. J Med Case Rep 2012;6:231.

13. Ebato T, Yamamoto T, Abe K, Ishii T, Kuyama Y. Endoscopic removal of localized gastric amyloidosis. Endoscopy 2012;44 Suppl 2 UCTN:E351.

14. Yamaguchi T, Inoue T, Nishida T, et al. Localized gastric amyloidosis mimicking a submucosal tumor-like gastric cancer. Gastrointest Endosc 2015;82:175-177.

15. Kagawa M, Fujino Y, Muguruma N, et al. Localized amyloidosis of the stomach mimicking a superficial gastric cancer. Clin J Gastroenterol 2016;9:109-113.

16. Gentry M, Pettenati M, Pang CS. Biclonal light chain gammopathy with aberrant CD33 expression in secondary plasma cell leukemia. Int J Clin Exp Pathol 2013;6:2224-2229.

17. Jiwani S, Bornhost J, Alapat D. Biphenotypic plasma cell myeloma: two cases of plasma cell neoplasm with a coexpression of kappa and lambda light chains. Int J Clin Exp Pathol 2015;8:8536-8544. 